\section{Root-zone Carbon Dioxide \\ Enrichment in Field Does Not Improve Tomato or Cucumber Yield}

T.K. Hartz and D.B. Holt

Department of Botany and Plant Sciences, University of California, Riverside, CA 92521

Additional index words. drip irrigation, Cucumis sativus, Lycopersicon esculentum

Mauney and Hendrix (1988) reported that $\mathrm{CO}_{2}$-saturated irrigation water increased $\mathrm{P}$, $\mathrm{Mn}$, and $\mathrm{Zn}$ uptake and vegetative growth and boll count in cotton. Nakayama and Bucks (1980) found that delivering $\mathrm{CO}_{2}$-amended water through a drip irrigation system increased wheat yields. Based on these and other reports (D'Orazio, 1990), California and Arizona growers have begun to adopt this technique in the field on a variety of crops. This study was conducted to determine the effects of $\mathrm{CO}_{2}$-amended irrigation water on tomato and cucumber production.

Field experiments were conducted in Summer 1990, at Riverside and Irvine, Calif. Soil types were Buren fine sandy loam (mixed, thermic Haplic Durixeralf) in Riverside and San Emigdio sandy loam [mixed (calcareous), thermic Typic Xerofluvent] in Irvine. Raised beds on $1.5-\mathrm{m}$ centers were prepared, with single drip irrigation lines buried $15 \mathrm{~cm}$ in the center of each bed. Beds at Irvine were mulched with black polyethylene film. 'Dasher II' cucumber (Cucumis sativus L.) seed and 'Bingo' tomato (Lycopersicon esculentum Mill.) transplants were planted on 1 June (Irvine) or 5 June (Riverside); plant population was 17,000 and $29,000 /$ ha for tomato and cucumber, respectively.

Beginning 3 weeks after planting, bottled

Received for publication 17 Dec. 1990. The cost of publishing this paper was defrayed in part by the payment of page charges. Under postal regulations, this paper therefore must be hereby marked advertisement solely to indicate this fact.
$\mathrm{CO}_{2}$ was injected continuously into the irrigation stream at either $1.0 \mathrm{~g} \cdot$ liter $^{-1}$ (both sites) or $0.5 \mathrm{~g} \cdot \operatorname{liter}^{-1}$ (Irvine only). Carbon dioxide-amended and control (unamended) plots received equivalent amounts of water. Irrigation was delivered three times per week, based on estimated evapotranspirational (ET) demand. Upon achievement of full plant canopy, irrigation frequency was increased to daily application at Riverside, which had higher ET rates. The design was randomized complete block with five (Riverside) or four (Irvine) 8-m replications per crop.

Carbon dioxide amendment acidified the irrigation water, causing a drop in $\mathrm{pH}$ of $\approx 2.0$ units (from $\approx 7.3$ to 5.3 ) at $1.0 \mathrm{~g} \cdot$ liter $^{-1} \mathrm{CO}_{2}$. This $\mathrm{pH}$ change was transitory in these soils, with soil solution samples drawn 1 day after irrigation showing only marginal $\mathrm{pH}$ depression. Conventional tissue testing showed no significant differences among treatments in tissue nutrient concentrations.

At Riverside, $\mathrm{CO}_{2}$ amendment of irrigation water had no effect $(P=0.10)$ on marketable yield of tomato or cucumber $(75 \pm$

Table 1. Effects of root-zone $\mathrm{CO}_{2}$ enrichment on tomato and cucumber yield at Irvine, Calif.

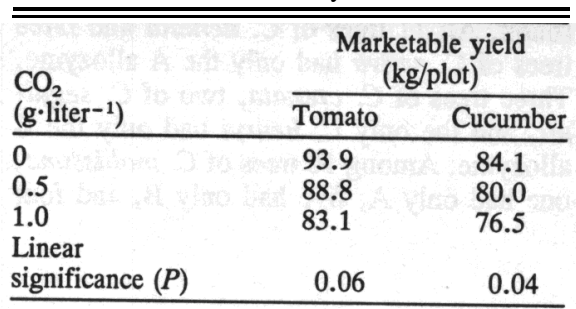

2 and $69 \pm 1 \mathrm{~kg} /$ plot, respectively); at Irvine, yields of tomato and cucumber decreased linearly with increasing level of $\mathrm{CO}_{2}$ injection (Table 1). The detrimental effect of $\mathrm{CO}_{2}$ treatment at Irvine may have been related to the use of plastic mulch. Mulch increases $\mathrm{CO}_{2}$ concentration in the soil atmosphere; further addition of $\mathrm{CO}_{2}$ through water injection may have resulted in supraoptimal concentrations that appear to have been detrimental to yield. At Irvine, irrigation was less frequent but of longer duration, so the length of time in which soil atmosphere $\mathrm{CO}_{2}$ was elevated and the maximum soil $\mathrm{CO}_{2}$ concentration associated with each irrigation may have been more extreme. The higher overall productivity of the Irvine site is consistent with well-documented beneficial effects of plastic mulch on these crops.

The results of these field studies are in contrast to earlier reports on other crops suggesting beneficial results from this treatment. However, other research has demonstrated that plant response to root-zone $\mathrm{CO}_{2}$ enrichment is strongly influenced by environmental factors (Baron and Gorski, 1986). Species also respond differently (Nakayama and Bucks, 1980; Stolwijk and Thimann, 1957). Clearly, a better understanding of the mechanisms of action and the influence of other environmental factors is required before root-zone enrichment can be advocated as a commercial production practice.

\section{Literature Cited}

Baron, J.J. and S.F. Gorski. 1986. Response of eggplant to a root environment enriched with $\mathrm{CO}_{2}$. HortScience 21:495-498.

D’Orazio, R. 1990. Big gains from carbonating irrigation water. Ag Consultant 46(7):14-15.

Mauney, J.R. and D.L. Hendrix. 1988. Responses of glasshouse grown cotton to irrigation with carbon dioxide-saturated water. Crop Sci. 28:835-838.

Nakayama, F.S. and D.A. Bucks. 1980. Using subsurface trickle system for carbon dioxide enrichment. Proc. 15th Natl. Agr. Plastics Congr., Tucson, Ariz., 13-17 Apr. p. 13-18.

Stolwijk, J.A.J. and K.V. Thimann. 1957. On the uptake of carbon dioxide and bicarbonate by roots, and its influence on growth. Plant Physiol. 32:513-520. 